\section{小膵管の上皮化生に関する 病理組織学的研究}

\section{緒 言}

膵疾患の中で病理形態学的検索は糖尿病 ${ }^{1)}$, 原発性膵癌 2 (2) 3) 及び急性膵炎 ${ }^{4)}$ 亿関して代表的 な業績が古くより知られて敊り，所見そのもの については多くの著者の意見で一致するところ が多い。しかし膵外分泌を主として傷害する と考元らるるわゆる慢性胿炎についてはその 病理学的定義づけもまだ充分でなく Opie ${ }^{5)}$ (1902), 近年になって Bell ${ }^{6)}$ (1958), Dreiling ら ${ }^{7)}$ (1965) のほか Sarles ら ${ }^{8)}$, 高末9), 小島ら ${ }^{10)}$ 等の業績がみられるが未だ十分でなく 特に臨床所見と病理所見との相関については膵 組織が自己融解し易いこと, 臨床検査法や臨床 診断法の困難であることも原因となってこの方 面の研究が他の領域よりも遅れていたことは否 定し難い事実であった。しかし最近慢性㓐炎が 上腹部不定愁訴の原因として重視されるように なり Ägren ら ${ }^{11)}$ (1936), Bartelheimer ら ${ }^{12)}$ (1955), Dreiling ら ${ }^{13)}$ (1961) 等による胃十 二指腸ゾンデの改良による純粋な臆外分泌液の 分割採取法の進歩と相俟って Howatt ${ }^{14)}$ (19 58), Sun ${ }^{15)}$ (1965) 等によるパンク.レオザイ ミン, セクレチン試験等各種の機能検査の進 歩, 或いは低緊張性十二指腸造影16), さらには 膵管造影(17), 脺の動脈撮影 ${ }^{18)}$, 及びスキャンニ ング199等により臨床的アプローチが盛んになり つつある。著者は膵外分泌腺の導管の変化, 特 に扁平上皮化生に注目し, その形態発生, 発育 様式等について病理形態学的に検索し扁平上皮 化生が脺外分泌部に演ずる役割について検討し た。

順天堂大学医学部大学院学生 (病理学教室)

\section{須田耕一}

\section{材料及び研究方法}

昭和 40 年 10 月から 43 年 6 月まで及び 45 年 9 月 より 46年 7 月までの順天堂大学医学部病理学教 室における全剖検体数約 1,000 例から未熟児, 新生児及び原発性ないし続発性膵癌（癌浸潤は 脺管を機械的に圧迫し，又周囲に随伴性脺炎 伴なう20)ので除外した), さらに自己融解の強 いものを除いた無選択剖検脺 392 例について主 㓐管に直角な面で頭・体・尾を各ヶ 1 個切り出 し(必要に応じて各部位ごとに 1 ～個を追 加）通常の方法でパラフィン・ブロックとする か或いは可能な例についてはパラフィン切片の 変形を最少限にとどめる目的でセロイヂン・パ ラフィン包埋を行なった。 $4 \mu$ の薄切片につき $\mathrm{H} \cdot$ E染色, PAS 染色, エラスティカ・ワン ーギソン染色, Azan・Mallory 染色，ムチカ ルミン染色等を行なった。扁平上皮化生巣（特 に連続切片で拡がりを調べたものを化生巣とし た）の拡がりを検索するためには約 $5 \mu$ の厚さ で連続切片を300 500枚程度作製し描画復構術 を行なった。前記材料のうち96例については特 に十二指腸への胆管, 脺管開口部を Rienhoff

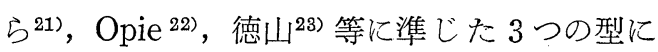
解剖学的に分類し, 前記 3 個 (頭 - 体 ・尾) に 加えて乳頭部を胆管, 脺管を含めて切り出し, 乳頭部開口型式と上皮化生との関係も合わせ調 ベた。

\section{結 果}

1）出現頻度（表 1）：前記条件, 即ち未熟 児, 新生児, 癌浸潤のあるもの及び自己融解の 強いものを除いた無選択剖検膵 392 例中扁平上 皮化生を認めるもの121例 (30.9\%), 同じく杯 
表 1 上皮化生の出現頻度（392例）

\begin{tabular}{c|c|cc|cc} 
& 総 数 & \multicolumn{2}{|c|}{ 扁平上皮化生 } & \multicolumn{2}{|c|}{ 杯細胞化生 } \\
\hline 男 & 248 例 & 74 例 & $(29.8 \%)$ & 121 例 & $(48.8 \%)$ \\
\hline 女 & 144 & 47 & $(32.6)$ & 85 & $(59.6)$ \\
\hline 計 & 392 & 121 & $(30.9)$ & 206 & $(52.6)$ \\
\hline
\end{tabular}

細胞化生を 206 例 (52.6\%) 飞認めた。又性別 で注男性注 248 例中扁平上皮化生 74例 (29.8 \%), 杯細胞化生121例（48.8\%）であり，同様 に女性沙 144 例中 47 例 $(32.6 \%), 85$ 例 $(59.6$ \%)であった。

2）部位別出現頻度（表 2）：膵の頭・体・ 尾の部位別出現頻度では 2 力所以上みられるも のでは加算して扁平上皮化生は頭部69例，体部 64例，尾部70例であり，杯細胞化生も同様に 155例， 120 例，129例であった。

表 2 部位別出現頻度

\begin{tabular}{c|c|c}
\hline 部 位 & 扁平上皮化生 & 杯細胞化生 \\
\hline 頭 & 69 例 & 155例 \\
\hline 体 & 64 & 120 \\
\hline 尾 & 70 & 129 \\
\hline
\end{tabular}

3）年令的分布（表 3）：扁平上皮化生は 17 才から88才までに認められ平均 57.4 才であり， 同様注杯細胞化生は15才から88才までで平均 58.2 才である。各年令階層別の出現頻度の折れ 線グラフ（図 1) 觉作ると上皮化生の頻度浪何 表 3 上皮化生の年令分布

\begin{tabular}{|c|c|c|c|c|c|}
\hline 年 令 & 総数 & 扁平上 & 化生 & 杯細脸 & 化生 \\
\hline$\sim 10$ & 19例 & O例 & $0 \%$ & 1例 & $5.3 \%$ \\
\hline $11 \sim 20$ & 14 & 1 & 7.1 & 2 & 14.3 \\
\hline $21 \sim 30$ & 34 & 8 & 23.5 & 10 & 29.4 \\
\hline $31 \sim 40$ & 40 & 11 & 27.5 & 18 & 45.0 \\
\hline $41 \sim 50$ & 54 & 16 & 29.6 & 25 & 46.3 \\
\hline $51 \sim 60$ & 78 & 26 & 33.3 & 47 & 60.2 \\
\hline $61 \sim 70$ & 92 & 31 & 33.7 & 58 & 63.0 \\
\hline $71 \sim 80$ & 50 & 22 & 44.0 & 35 & 70.0 \\
\hline $81 \sim$ & 11 & 6 & 54.5 & 10 & 90.9 \\
\hline 計 & 392例 & 121例 & $30.9 \%$ & 206例 & $52.6 \%$ \\
\hline
\end{tabular}

れも年令に比例して増加している。増加率をグ ラフでみると阫平上皮化生では生後より25才前 後までは直線的に急公配を示すがそれ以後は65 才前後までの間は約 $10 \%$ の昇を学当程度のゆ るい勾配で上昇する。65才以後は再び急角度の 上昇定示し, 最高85才前後で約 $55 \%$ の出現率军 示した。杯細胞化生については全体に同じょう

図 1 扇平上皮, 杯細胞化生の年令分布

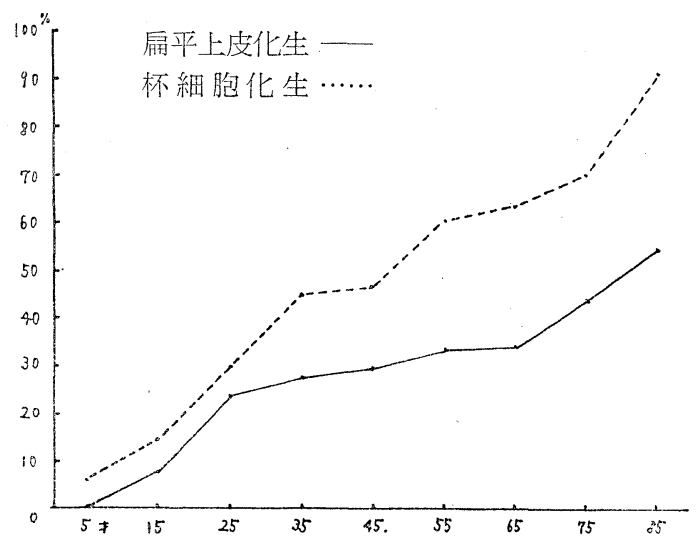

な勾配であるが45才前後，65才前後で勾配がゆ るやかである。

4）脺管上皮化生の疾患別出現頻度（表4）： 主病変による疾患別頻度の高いものは扁平上皮 化生では糖尿病17例中 8 例 (47.1\%), 肝硬变 13例中 6 例 $(46.2 \%)$, 腎尿路系腫痬 9 例中 4 例 $(44.4 \%)$, 脳血管障害16例中 7 例 $(43.8 \%)$, 心筋硬塞18例中 9 例 $(50 \%)$ 等であり，杯細胞 化生では肝硬变念めた肝胆系疾患 (先天性胆 道閉塞恰除く） 21 例中17例 (81.0\%), 脳血管 障碍 16 例中11例 $(68.8 \%$ ), 心筋硬塞18例中13例 (72.2\%), 循環障害26例中18例 $(69.2 \%)$ 等で ある。

5）十二指腸乳頭部に抢方胆管・㓐管開口 型式と上皮化生との関係（表 5)：96例につい $\tau$ Rienhoff ら ${ }^{21)}$, Opie ${ }^{22)}$ ，德山等に準じ た 3 つの型に開口部を解剖学的に分類・検索す ると I 型（胆管・膵管の分離開口） は 2 例 (2.1 \%), II 型（一乳頭であるが分離開口）は 14 例 (14.6\%), III型（共通開口, 所謂膨大部安もつ 
もの）は80例（83.3\%）で扁平上皮化生はそれ ぞれ50\%，57.1\%，33.8\%で，同様に杯細胞化 生は 100\%，57.1\%，53.8\%であった。さらに

表 4 主病变による疾患別出現頻度

\begin{tabular}{|c|c|c|c|c|c|c|}
\hline \multicolumn{2}{|c|}{ 疾患名(主病恋) } & 例数 & \multicolumn{2}{|c|}{ 扁平上皮化生 } & \multicolumn{2}{|c|}{ 杯細胞化生 } \\
\hline \multirow{3}{*}{ 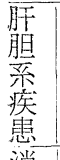 } & 肝胆系腫瘍 & 16例 & 6例 & $37.5 \%$ & 8例 & $50.0 \%$ \\
\hline & 肝 硬 変 & 13 & 6 & 46.2 & 10 & 76.9 \\
\hline & そ の 他 & 8 & 1 & . 12.5 & 7 & 87.5 \\
\hline \multirow{3}{*}{$\begin{array}{l}\text { 消 } \\
\text { 华 } \\
\text { 管 } \\
\text { 㙜 }\end{array}$} & 胃腸疾患 & 10 & 2 & 20.0 & 6 & 60.0 \\
\hline & 癌 & 28 & 3 & 10.7 & 13 & 46.4 \\
\hline & 癌 & 13 & 4 & 30.8 & 4 & 30.8 \\
\hline \multirow{3}{*}{$\begin{array}{l}\text { 蒗 } \\
\text { 䒺 } \\
\text { 腫 } \\
\text { 瘍 }\end{array}$} & 腎尿路系腫瘍 & 9 & 4 & 44.4 & 5 & 55.6 \\
\hline & 男性器腫瘍 & 4 & 1 & $25 \cdot 0$ & 1 & 25.0 \\
\hline & 女性器腫瘍 & 15 & 2 & 13.3 & 5 & 33.3 \\
\hline \multicolumn{2}{|c|}{$\begin{array}{l}\text { その他 } \\
\text { 腹腔内腫瘍 }\end{array}$} & 6 & 2 & 33.3 & 5 & 83.3 \\
\hline \multirow{4}{*}{$\begin{array}{l}\text { 腹 } \\
\text { 腔 } \\
\text { 外 } \\
\text { 腫 } \\
\text { 瘍 }\end{array}$} & 癌 & 27 & 10 & 34.5 & 17 & 63.0 \\
\hline & 食 道 癌 & 9 & 2 & 22.2 & 5 & 55.6 \\
\hline & 脳 腫 瘍 & 21 & 7 & 33.3 & 6 & 28.6 \\
\hline & そ の他 & 8 & 0 & 0 & 4 & 50.0 \\
\hline \multirow{5}{*}{$\begin{array}{l}\text { 血 } \\
\text { 管 } \\
\text { 障 } \\
\text { 害 } \\
\text { 病 }\end{array}$} & 糖 尿 病 & 17 & 8 & 47.1 & 8 & 47.1 \\
\hline & 萎 縮 腎 & 30 & 9 & 30.0 & 14 & 46.7 \\
\hline & 脳血管障短 & 16 & 7 & 43.8 & 11 & 68.8 \\
\hline & 心筋硬塞 & 18 & 9 & 50.0 & 13 & 72.2 \\
\hline & 循環障害 & 26 & 10 & 38.5 & 18 & 69.2 \\
\hline \multirow{4}{*}{\multicolumn{2}{|c|}{$\begin{array}{l}\text { 感 染 症 } \\
\text { 膠 原 病 } \\
\text { 血液疾 患 } \\
\text { そ }\end{array}$}} & 13 & 3 & 23.1 & 4 & 30.8 \\
\hline & & 7 & 2 & 28.6 & 2 & 28.6 \\
\hline & & 21 & 6 & 28.6 & 8 & 38.1 \\
\hline & & 57 & 17 & 29.8 & 32 & 56.1 \\
\hline
\end{tabular}

表 5 十二指腸乳頭部における胆管・膵管の開口型式と膵管の 上皮化生との関係

\begin{tabular}{|c|c|c|c|c|c|c|c|c|c|c|c|c|}
\hline \multicolumn{3}{|c|}{ 十二指腸乳頭開口部 } & \multicolumn{5}{|c|}{ 扁平上皮化生 } & \multicolumn{5}{|c|}{ 杯 細 胞 化生 } \\
\hline \multirow{2}{*}{ 開 口 型 式 } & \multirow{2}{*}{\multicolumn{2}{|c|}{$\begin{array}{l}\text { 頻 度 } \\
\text { (96例) }\end{array}$}} & \multirow{2}{*}{ 頻 } & \multirow{2}{*}{ 度 } & \multicolumn{3}{|c|}{\begin{tabular}{|l} 
部位別 \\
例 数
\end{tabular}} & \multirow{2}{*}{ 頻 } & \multirow{2}{*}{ 度 } & \multicolumn{3}{|c|}{$\begin{array}{l}\text { 部位. 別 } \\
\text { 数 }\end{array}$} \\
\hline & & & & & 頭 & 体 & 尾 & & & 頭 & 体 & 尾 \\
\hline 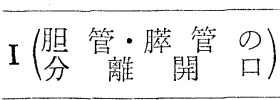 & & & $\begin{array}{r}\text { 例 } \\
1 / 2\end{array}$ & $\begin{array}{r}\% \\
50.0\end{array}$ & & 1 & & $\begin{array}{r}2 \text { 例 } \\
/ 2\end{array}$ & $\begin{array}{r}\% \\
100\end{array}$ & $b$ & 2 & \\
\hline 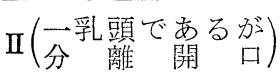 & 14 & 14.6 & $8 / 14$ & 57.1 & 5 & 1 & 4 & $8 / 14$ & 57.1 & 5 & 4 & 7 \\
\hline 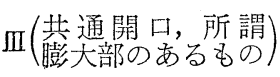 & 80 & 33. & $27 / 80$ & 33.5 & 20 & 12 & & $42 / 80$ & 52.5 & 536 & 25 & 521 \\
\hline
\end{tabular}

(96例)

部位別にみると屚平上皮化生で I 型では体部に 1，II型では頭部 5 , 体部 1 , 尾部 4 , III型で

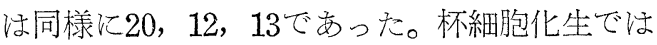
I 型で頭部 1 , 体部 2 , II 型で頭部 5 , 体部 4 , 尾部 7, III型で同樣に36，25，21であっ た。

6）扁平上皮化生と脺所見の関俰（表 6）： 膵管拡張, 管内膵液うっ滞, 杯細胞化生, 腺房 拡張, 細胞浸潤, 線維化, 動脈硬化及び脂肪浸 潤の各要素から久た扁平上皮化生定伴交うもの と，伴なわないものとの膵組織所見を比較し た。ここで線維化と動脈硬化を除いた他の要素 は少しでも認められるものはすべて陽性とし た。線維化については管周囲性の線維化は一般 に余り变化のない膵でも認められるので除外 し，弱拡大で観て線維化がびをえ性にあるもの を陽性とした。動脈硬化については脾動脈等の 太い血管は除き，脺内に分布する血管にのみ注 目し内膜の肥厚しているものを陽性とした。以 上の点から扁平上皮化生定伴なうもの，そうで ないものを集計し比較すると扁平上皮化生它伴 なうもの (121例) では膵管の拡張69例（57.0 $\%$ ，膵液のうっ滞97例 $(80.2 \%)$, 杯細胞化生 91例 (75.2\%), 腺房拡張24例 (19.8\%), 細胞 浸潤76例 $(62.8 \%)$ ，線維化36例 $(29.8 \%)$ ，動 脈硬化 50 例 $(41.3 \%)$, 脂肪浸潤102例 (84.3\%) であった。俩平上皮化生空伴なわないもの(271 例) では同様に，77例 (28.4\%)，150例 (55.4 $\%), 115$ 例 (42.4\%), 50 例 $(18.5 \%), 130$ 例 $(48.0 \%), 70$ 例 $(25.8$ $\%), 94$ 例 $(34.7 \%), 197$ 例 $(72.7 \%)$ であった。 ランゲルハンス島につい ては特に取り上げなかっ た。

7) 碉平上皮化生巣の 拡がり（図 2 , 剖検番号 2516, 57 才우，子宮頸癌） : 連続切片にて扁平上皮 
表6 扁平上皮化生と膵 組織所見

\begin{tabular}{|c|c|c|c|c|c|c|c|c|}
\hline \multirow{2}{*}{$\begin{array}{l}\text { 組織所見 } \\
\text { 届 } \\
\text { 上皮化生 } \\
\end{array}$} & 膵 & & 管 & \multirow{3}{*}{\begin{tabular}{|r|} 
腺房拡張 \\
24 例 \\
$62.8 \%$ \\
\end{tabular}} & \multirow{3}{*}{\begin{tabular}{r|} 
細胞浸潤 \\
76 例 \\
$62.8 \%$ \\
\end{tabular}} & \multirow{3}{*}{\begin{tabular}{r|} 
線 維 化 \\
36 例 \\
$29.8 \%$ \\
\end{tabular}} & \multirow{3}{*}{\begin{tabular}{|r|} 
動脈硬化 \\
50 例 \\
$41.3 \%$ \\
\end{tabular}} & \multirow{3}{*}{$\begin{array}{r}\text { 脂肪浸潤 } \\
102 \text { 例 } \\
84.3 \% \\
\end{array}$} \\
\hline & 張 & \multicolumn{2}{|c|}{ 長 胿液うっ滞杯細胞化生 } & & & & & \\
\hline 有 り & $\begin{array}{r}69 \text { 例 } \\
57.0 \%\end{array}$ & $\begin{array}{r}97 \text { 例 } \\
80.2 \%\end{array}$ & $\begin{array}{r}91 \text { 例 } \\
75.2 \%\end{array}$ & & & & & \\
\hline 無 し 271例 & $\begin{array}{r}77 \\
28.4\end{array}$ & $\begin{array}{r}150 \\
55.4\end{array}$ & $\begin{array}{r}115 \\
42.4\end{array}$ & $\begin{array}{r}50 \\
18.5\end{array}$ & $\begin{array}{r}130 \\
48.0\end{array}$ & $\begin{array}{r}70 \\
25.8\end{array}$ & $\begin{array}{r}94 \\
34.7\end{array}$ & $\begin{array}{r}197 \\
72.7\end{array}$ \\
\hline 392例 & $\begin{array}{r}146 \\
37.2\end{array}$ & $\begin{array}{r}247 \\
63.0\end{array}$ & $\begin{array}{r}206 \\
52.6\end{array}$ & $\begin{array}{r}74 \\
18.9\end{array}$ & $\begin{array}{r}206 \\
52.6\end{array}$ & $\begin{array}{r}106 \\
.27 .0\end{array}$ & $\begin{array}{r}144 \\
36.7\end{array}$ & $\begin{array}{r}299 \\
76.3\end{array}$ \\
\hline
\end{tabular}

図 2 (剖検番号 $2516 ， 57$ 才，女性，子宮䅡癌）<胵管を開き，内側から 見た図, 点線は, その断面を写真で示す>扁平上皮化生巣（黒点） は膵管分岐部を中心にして出現し，大小種々で多発している。

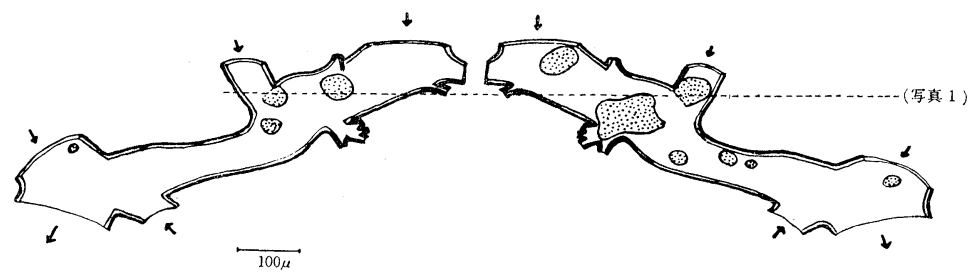

る終末部に执いて周囲 膵組織と明らかに異な る変化, 即ち腺房細胞 の扁平化, チモーゲン 顆粒の減少或いは腺房 の拡張及び間質の増加 を認めた（写真， 5, $6,7) 。$

iii）図 5 (剖検番号 2434, 51才ㅇ，急性骨 化生巣の拡がりを検索すると多くの場合，脺管 分岐部を中心として出現し（写真 1 ）大きさも 大小種々で追求し得た範囲では図 5 の如く約

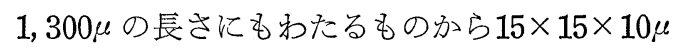
程度の小さいものまであり多発性に認められ る。

8）扁平上皮化生巣と末梢膵組織との関係 （図 3，4，5）：連続切片によって 3 例の描 画を作製した。

i ) 図 3 (剖検番号 $2741,66 才$ 才 , 糖尿病) : 脺管分岐部に約 $175 \times 150 \times 100 \mu$ の大ささの 扁平上皮化生巣があり内腔を狭窄し，そのため 遠側膵管の囊状拡張と膵液のうっ滞があり管上 皮は一部で扁平化している(写真 2 ), 化生巣は 内腔にポリープ状に突出しており，その尖端を 近位側に向けている(写真 3 )，或いはまた管壁 から間質側に向って膨隆するが，乙の際，上皮 基底膜は破られていない(写真 4)。

ii）図 4 (剖検番号 2848,68 才。, 直腸癌) : 扁平上皮化生巣が脺管分岐部にあり遠側胿管 の拡張及び膵液のうっ滞がタられ，その所属す

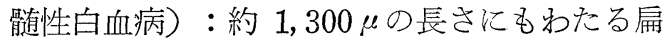
平上皮化生巣があり，その大部分で胿管内腔の 全周にわたって環状を呈し(写真 8$)$ ，とれより 近位では膵液の流れに沿ってポリープ状に内腔 に突出し(写真 9 ), その所属する終末部に小葉 間線維化が認められ, 各腺房は踈開の傾向定示 している(写真10,11)。

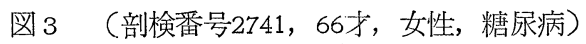

膵管分岐部の扁平上皮化生巣が内腔を狭窄 し, 遠側膵管の囊状拡張々膵液のうっ滞が あり,化生巣は内腔にポリープ状に突出し， その尖端を近位側に向け，或いはまた管壁 から間質側に向け膨隆している。

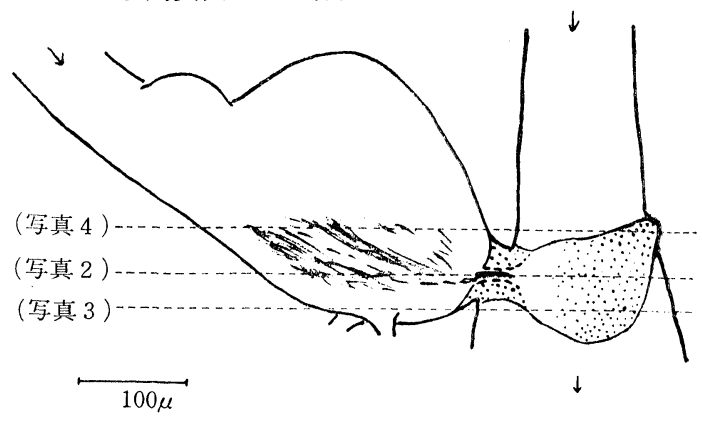


図 4 (剖検番号2848，68才，男性，直腸癌）

膵管分岐部に扁平上皮化生巣があり, 遠位膵管の拡張, 膵液のうっ滞が

みられ，さらに限局性の腺房拡張，間質の増加等を認める。

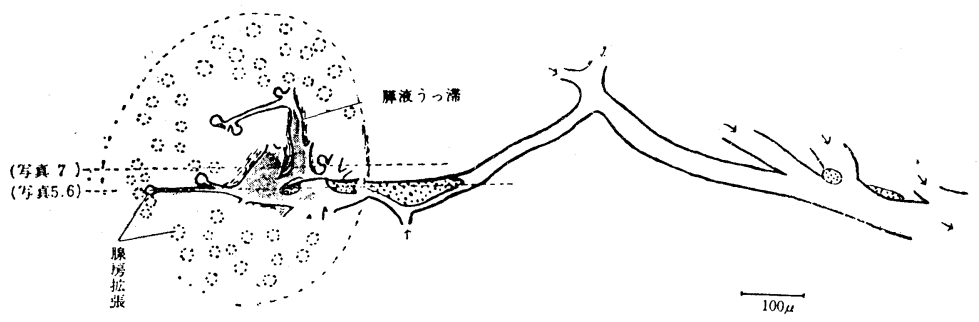

の采統の組織に变化す ることをいい，原因と 乙て慢性炎症, 化学 的, 物理的刺激等があ げられている24)。脺管 の扁平上皮化生の原因 については

i ) 慢性刺激25)

ii）膵管上皮に対す る保護作用25)

iii）ビタミンAの欠

\section{考擦}

一般に組織の化生とは, 分化した組織から他

図 5 （剖検番号2434，51才，女性，急性骨 髄性白血病)

約 $1,300 \mu$ の長さにわたる化生巣があり, 大 部分で膵管を環状に全周置きかえ, 近位では 膵液の流れに沿って内腔にポリープ状に突出 している。所属する終末部では小葉間線維化 が認められる。

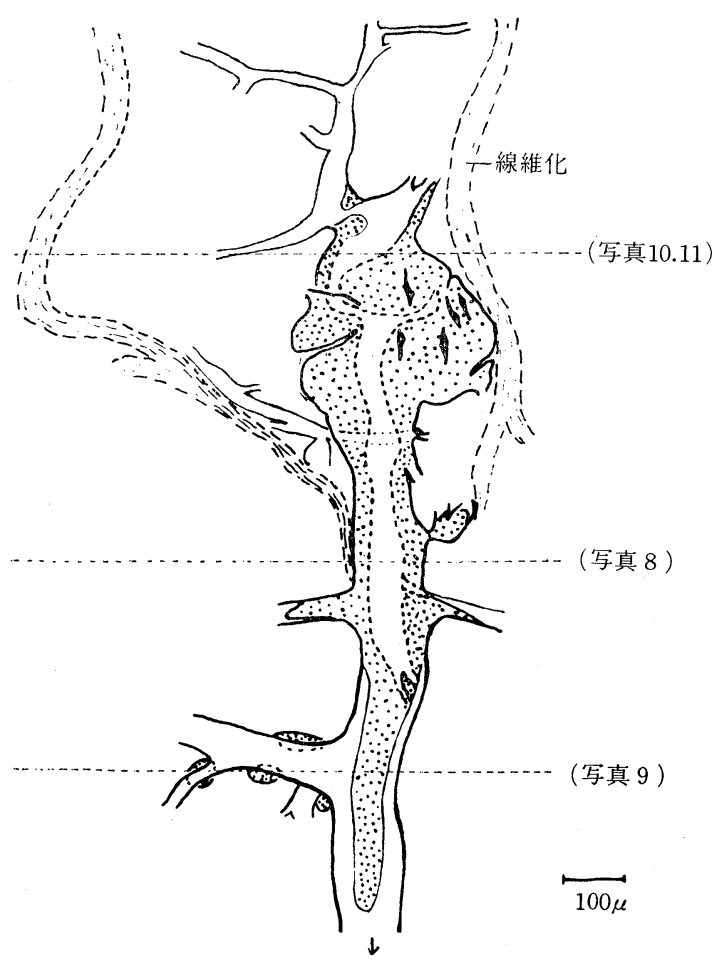

乏による角化作用25), 26)

iv) 線維化, 特に杯細胞化生は阻血性病变に 基く腺房萎縮があって, 実質を線維組織が置換 し，そのために生ずる小脺管の閉塞により予備 細胞 reserve cells (未分化細胞, 腺房中心細 胞）が増殖することによって起こると云われて いる ${ }^{27), 28)}$ 。

v) 各種の毒素・菌 ${ }^{29)}$, 寄生虫等で Chan Po Hon ${ }^{30)}$ (1967） は肝ジストマの24例中14例 （58\%）に化生を認めている。

又上皮化生の起原に関し Blumenthal $5^{25)}$ によると扁平上皮化生は上皮細胞の变化ではな くて上皮細胞と線維性壁との間にみられる細胞 (lining cells)の増殖及び成熟によって起ると いい，先きに Laidlaw ${ }^{31}$ (1938）も同様な細胞 が脺管閉塞等の異常があるとチモーゲン産生細 胞等として関与し線維化のような, さらに続く 刺激があると杯細胞化ないし余り多くないが扁 平細胞の像を呈すという。又杯細胞化生はBlumenthal ら ${ }^{25)}$ により始めて記載され予備細胞 として働く腺房中心性上皮細胞 (Centro-acinar ductular cells）の増殖及び成熟によって起き るという。

扁平上皮化生の出現頻度に関し Priesel ${ }^{32)}$ は 140例中13例 (8.2\%) 飞認め, Yotsuyanagi ${ }^{34)}$ は最も多く64\%にみられるとし，一番低いのは Wainright ${ }^{36)}$ の3.2\%である。著者は 392例中 扁平上皮化生を 121 例（30.9\%）に認め, 諸家

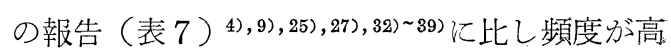


い。その理由法著者によって切り出し部位, ブ ロックの個数等の記載がまちをちであることに もより，用いた剖検例の性質にもよると思われ る。著者の方法は前述の通り切り出し部位, ブ ロック数は，ほぼ一定で相当数の標本字鏡検し 得たので化生巣を比較的多数発見乙得たとい うことも考光られる。又杯細胞化生活206例 (52.6\%) 亿認められ，乙れは杯細胞定少しで も認好たの丧陽性としたため高頻度を示した 之考光られる。性別出現頻度で注男性は248例 中杯細胞化生121例 (48.8\%) で女性の144例中 85例 (59.6\%) と比較し男性の方がやや少ない が扇平上皮化生では29.8\%と32.6\%で有意の差 は認められなかった。

上皮化生の部位別出現頻度に関し Yotsuyanagi ${ }^{34)}$ は府平上皮化生が頭>体>尾の順で頭 部に多い，又高木99 は尾部に多いとしているが 自験例では頭部69, 体部64, 尾部70と特徴が無 い。一方杯細胞化生々 155，120，129 と頭部が 他と比べ多いの核興味深く Blumenthal ら 25) も十二指腸乳頭部の近くに頻度が高いとし，上 皮細胞の保護作用と関係が深いと考えられる。

Blumenthal ら ${ }^{25)}$ （1959） ほ上皮化生の年令 的出現頻度を111例について調べると扁平上皮, 杯細胞化生とも頻度が51 60才で最も高く以後 減少していて，乙の勾配注急性膵炎の年令分布 表 7 上皮化生 9 文献例一覧

\begin{tabular}{|c|c|c|c|c|c|c|}
\hline \multirow{3}{*}{$\begin{array}{l}\text { 報 告 } \\
\text { Priesel } \\
\text { Balo \& Ballon }{ }^{33)}\end{array}$} & \multirow{2}{*}{$\frac{\text { 者 }}{\text { 1922年 }}$} & \multirow{2}{*}{$\frac{\text { 症例数 }}{140 \text { 例 }}$} & \multicolumn{2}{|c|}{ 啢平上皮化生 } & \multicolumn{2}{|c|}{ 杯細胞化生 } \\
\hline & & & 13例 & $8.2 \%$ & 例 & $\%$ \\
\hline & 1929 & 160 & 14 & 8.7 & & \\
\hline Yotsuyanagi ${ }^{34)}$ & 1931 & 78 & 50 & 64 & & \\
\hline Rich. \& Duff ${ }^{4)}$ & 1936 & 150 & 28 & 18.6 & & \\
\hline Korápssy ${ }^{35)}$ & 1938 & 500 & 58 & 11.6 & & \\
\hline Wainright ${ }^{36)}$ & 1951 & 2,500 & 81 & 3.2 & & \\
\hline Andrew ${ }^{37)}$ & 1957 & 55 & 28 & 51 & & \\
\hline Becker ${ }^{38)}$ & 1957 & 300 & 70 & 23 & & \\
\hline Blumenthal $5^{25)}$ & 1959 & 111 & 18 & 17.2 & 28 & 25.2 \\
\hline 高木 ${ }^{9)}$ & 1964 & 257 & 30 & 11.2 & & \\
\hline Walter ${ }^{27)}$ & 1965 & 200 & 10 & 5.0 & 55 & 27 \\
\hline Martin ${ }^{39)}$ & 1965 & 180 & 28 & 15.5 & 12 & 6.6 \\
\hline 著者 & 1972 & 392 & 121 & 30.9 & 206 & 52.6 \\
\hline
\end{tabular}

と非常に平行するという。乙れ注60才以後に腺 房細胞等に老化が始まり肸酵素の分泌の減少が 起こるためであり，そのため上皮化生も減少す るといい, Yotsuyanagi ${ }^{34)}$ も30〜40才に好発 するという。一方高木9 ${ }^{9)}$ 洼高年者群に多いとし て打り Feldman ${ }^{40)}$ (1955）注上皮化生学老化 の一つにあげている。自験例でも年代を追って 増え 85 才前後で最も多い。即ち加令的増加で慢 性刺激ないし慢性炎症を支持する所見と考元ら れる。

疾患別出現頻度に関してWalter ${ }^{27}$ (1965) は 心血管系疾患に $22 \%$ ，胆管系疾患に $32 \%$ ，肝疾 患に $14 \%$ と扁平上皮化生がみられ，心血管系及 び肝胆系疾患汇多いとしているが高木 ${ }^{91}$ は疾患 による有意差を認めていない。著者の主病変に よる疾患別では陑平上皮化生は糖尿病, 肝硬变, 腎尿路系腫場，脳血管障碍，心筋硬塞等に多い。 脳血管障碍, 心筋硬塞等以高年層に多いので考 慮する必要がある。杯細胞化生で注肝硬变点含 內た肝胆系疾患, 脳血管障碍, 心筋硬塞, 循環 障碍等で多く, 肝胆系疾患で多いのは部位別出 現で頭部に多いことも考光合わせ注目される。

十二指腸乳頭部における胆管・㓐管開口型式 と脺所見との関係注 Hicken ら ${ }^{41)}$ (1952) によ ると開口部の種類には関係なく逆流現象分起

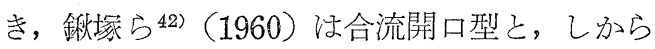
ざるものとの間に臨床例 の場合と同様に脺の組織 学的変化にも有意の差は なかったという。著者は 96例について Rienhoff $ら^{21)}$, Opie ${ }^{22)}$, 徳山注 等に準じた 3 つ型に十 二指腸における胆管, 脇 管開口型式を分類したが I 型（胆管・膵管の分離 開口）及びII型（一乳頭 であるが分離開口) では 例数が少ないが両化生と も50\%以上と III型（共通 
開口）に比較し出現頻度が高い。部位別出現例 数では I， II型では例数が少ないため傾向がつ かみにくいが而型では扁平上皮, 杯細胞化生と も頭部に多く共通開口という点を合わせ考える と頭部に新ける上皮化生は胆管系病变と何らか の関連があるものと考えられる。

扁平上皮化生のみら癿る脺では化生を伴なわ ない膵と比較し全体に何らかの変化がみられる が，特に臎管の変化が著しい。即ち膵管の拡 張，管内の胿液うっ滞及び杯細胞化生が目立 方, 次いで細胞浸潤, 脂肪浸潤, 動脈硬化及び 線維化であり，腺房の拡張は余り著明でなかっ た。つまり届平上皮化生のみられる㓐ではそう でないものに比較し脺管系の変化が強く, 終末 部, 間質, 血管の変化は軽度で, このことは屚 平上皮化生が，いわば㓐管のある局所に限局し た変化であって脺全体にまでは変化が及んでい ないことを示している。

膵管と扁平上皮化生との関係安多ると高不 ${ }^{9}$ ほ府平上皮化生を内腔増殖型と管壁增殖型に分 けているが著者は連続切片により検索すると i ）㓐管壁から内腔に突出するもの（㓐液の流 れ沿ってポリープ状をなしている）（写真 3,9 )。

ii）管周囲間質に向って基底膜定保ちつつ突 起状をなすもの(写真 4 )。

iii）環状に全周にわたり既存の管壁を置きか えているもの(写真 8$)$ 。

があり，さらに注目すべき事は扁平上皮化生の 多くは脺管分岐部它中心にして起こり（図 2 ,

$3,4,5$; 写真 $1,2,9)$ 大きいものでは 図 5 の如く約 $1.300 \mu$ の長さをもつものから小 さいものでは $15 \times 15 \times 10 \mu$ 程度のものまで大小 種々で多発性に出現している。脺管分岐部に多 いことは膵液の流れ等の諸因子の関与が予想さ れるが直接の因果関係は不明である。多発性に 出現することは頭・体・尾の 3 力所全てに出現 しているものもあることかみても明らかであ る。

扁平上皮化生の悪性化について Lowry ら ${ }^{4}$
（1949）注扁平上皮癌を 1 例報告し，扁平上皮 化生の周囲にみられたとしているが自験例では 扁平上皮化生の悪性化は認めていない。

上皮化生と末梢側膵所見との関係について Rich \& Duff ${ }^{4)}$ (1936） は上皮化生による膵管 の部分的閉塞の形成が膵管及び腺房の拡張, さ らに膵液のうっ滞を起こし, やがて腺房が破裂 して脂肪壊死ないし小出血を起こすといい，

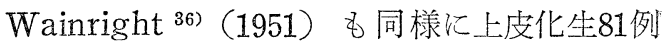
中49例に小胿管及び腺房の拡張を，14例に巣状 の線維化を，13例に脂肪壊死を認めている。

Berens ${ }^{44)}$ は㓐管の拡張の原因の一つに上皮化 生をあげている。Balo \& Ballon ${ }^{33)}$ (1929) も上皮化生が腺房細胞の㨄平化, 腺房の拡張, うっ滞さらに巣状壊死を起こすといい，その他 Priesel ${ }^{32)}$ は囊腫形成も起こすという。著者は 連続切片による 3 例の描画（図 $3,4,5$ ) か ら膵管分岐部の化生巣による内腔の狭窄によっ て遠側脺管の囊状拡張と膵液のうっ滞及び管上 皮細胞の扁平化ない乙剝離を認め(図 3,4 ) 又図 4 で注所属する終末部は周囲膵組織と所見 を明らかに異にする变化，即ち腺房細胞の扁平 化, チモーゲン顆粒の減少或いは腺房の拡張及 び腺房周囲間質の増加定認めた。図 5 では約 $1,300 \mu$ の長さにわたる扁平上皮化生巣があり, その大部分で㓐管它環状飞置さかえ末梢部に秥 いて限局性の小葉間線維化が認められ腺房細胞 は疎開の傾向を示している。以上より扁平上皮 化生による膵管の部分的閉塞と遠位㬳管及び腺 房の拡張, 㓐液のうつ滞や限局性線維化等との 関係が模式図によって明らかになり，このこと は扁平上皮化生を伴なった膵の組織所見からも 同様である。又囊腫の形成，巣状壊死及び脂肪 壊死等との関係ほ特に明らかにならなかった。 一般に腺房の拡張注尿毒症 ${ }^{45)}$, 潰瘍性大腸炎 46 , 及び肝硬変 ${ }^{47)}$ 等に多くみられ, びまえ性で電解 質のバランスや栄養等の代謝障害によると云わ れ, 又線維化, 特に局所性線維化については村 地 ${ }^{48)}$ は動脈硬化との関係を指摘しているが，小 葉単位以下の限局性に起きる脺管及び腺房の拡 
張, さらに線維化の原因としては脺管の扁平上 皮化生（特に内腔を狭窄するもの）をも考慮す る必要がある。

\section{結 論}

1）無選択剖検脺392例中扁平上皮化生121例 (30.9\%), 杯細胞化生 206例 (52.6\%) に認め た。

2）頭・体・尾の部位別出現頻度では杯細胞 化生は頭部にやや多かったが，扁平上皮化生で は特徴が無かった。

3）扁平上皮化生，杯細胞化生とも加令的に 増加する傾向が認められた。

4）主病変による疾患別出現頻度で法扁平上 皮化生で心筋硬塞, 糖尿病, 肝硬変, 脳血管障 碍の順に多く, 又杯細胞化生注肝胆系疾患, 循 環障碍，这血管障碍等で多かった。

5）十二指腸乳頭部における胆管 - 膵管開口 型式と化生の出現頻度とでは分離開口である I 型，II型に多く認められた。一方III型（共通開 口）における部位別出現例数では扁平上皮, 杯 細胞化生とも頭部に多かった。

6）届平上皮化生を伴なう脺は，そうでない ものに比較し全体に陽性所見があり膵管を中心 とした局所に強かった。

7）屙平上皮化生巣の拡がりはｉ）内腔に ポリープ状に突出するもの, ii）周囲間質に向 かうもの， iii）既存の管壁を環状に置きかえる もの等分けられる。

8）扁平上皮化生巣は脺管分岐部它中心にし て出現し，大小種々多発性であった。又特に悪 性化は認められなかった。

9）屙平上皮化生栄，特に内腔を狭窄するも のはその所属する小葉に扮いて限局性の線維 化, 腺房及び膵管の拡張と原因的関倸が考えら れる。

（本論文の要旨は第58回 (1969), 第59回 (1970), 第60回（1971）日本病理学会総会にて発表した。)

\section{引用文 献}

1) Warren, S. \& LeCompte, P. M. : The patho- logy of Diabetes Mellitus. Lea and Fehiger, Philadelphia, 1952.

2) Bell, E. T. : Carcinoma of the pancreas. I. A clinical and pathologic study of 609 necropsied cases. II. The relation of carcinoma of the pancreas to diabetes mellitus. Amer. J. Path. 33, 499-523, 1957.

3）石井兼央：日本癌治療学会シンポジウム「葫癌の 診断と治療」 1957.

4) Rich, A. R. \& Duff, G. L. : Experimental and pathological studies on pathogenesis of acute hemorrhagic pancreatitis. Bull. Johns Hopkins Hosp. 58, 212-259, 1936.

5) Opie, E. L. : The cause and varieties of chronic interstitial pancreatitis. Amer. J. Med. Sci. 123, 845-868, 1902.

6) Bell, E. T. : Pancreatitis. Surgery 43, 527537, 1958.

7) Dreiling, D. L., Janowitz, H. D. \& Perrier, C. V. : Pancreatic inflammatory disease. A physiologic approach. Hoeber Med. Division, Harper and Row, 1965.

8) Sarles, H. (edited): Proposal adopted unanimously by the participants of the symposium, Pancreatitis, Symposium, Marseilles, 1963.

9) 高木俊孝: 膵臟の病理組織学的知見補遺一特に膵 外分泌部に扔ける結合織増生について一, 順天堂 医学，9，146 170，1964.

10）小島国次，菅又宏，岡村明治：慢性膵炎の病理, 日病会誌, 57 (補), 35 47, 1968.

11) Ägren, G. Lagerhöf, H.: The pancreatic secretion in man after intravenous administration of secretion. Acta Med. Scand. 90, 1-29, 1936.

12) Bartelheimer, H., Maring, H. \& Stimming, H. J. : Quantitative fraktionierte Pankreassaftuntersuchungen bei Pankreas sowie Gallenbegs und Leberkrankungen. Klin. W schr. 33, 160-174, 1955.

13) Dreiling, D. A. \& Janowity, H. D. : The measurement of pancreatic secretory function. Ciba foundation Symposium on the exocrine pancreas. Boston, Little Brown, 1961.

14) Howatt, H. T. : Investigation of pancreatic 
dysfunction in the modern trends in Gastroenterology. Second Series, London Bastterworth medical publications, 1958.

15) Sun, D. C. : Diagnostic tests for chronic pancreatic disease. Arch. Int. Med. 115, 5761, 1965.

16）土屋雅春他：十二指腸造影法の手技之診断的意 義. 日仏医学, 10,10 18, 1965.

17）大井至 : Fiberduodenoscope (FDS-Lb) による 内視鏡的膵管造影. 日消会誌，66，880～883, 1969.

18）田坂哠他：膵の動脈撮影. 日本臨床，23，769 $779,1965$.

19）内山暁：膵シンチグラフィー. 診療， $23 ， 1621$ 1626, 1970.

20) 井上照信他: 原発性膵癌の病理学的知見補遺, 特 に睡瘍随伴性膵炎に就て. 日病会誌, 60, 1971, (印刷中).

21) Rienhoff Jr., W. F. \& Pickrell, K. L. : Pancreatitis. An anatomic study of the pancreatic and extrahepatic biliary systems. Arch. Surg. 51, 205-219, 1945.

22) Opie, E. L. : The anatomy of the pancreas. Bull. Johns Hopkins Hosp. 14, 229-232, 1903.

23) 徳山武郎: ファーテル乳頭部領域の病理組織学的 知見補遺. 順天堂医学, 12, 77 94, 1966.

24) 武田勝男 : 新病理学総論. 南山堂, 昭和 32 年.

25) Blumenthal, H. T. \& Probstein, J. G. : Pancreatitis, a clinical-pathologic correlation. Charles C Thomas, Springfield, Illinois, 1959.

26) Wolbach, S. B. \& Howe, P. R. : Vitamin A deficiency in the Guinea-Pig. Arch. Path. 5, 239-253, 1928

27) Walters, M. N-1 : Goblet-cell metaplasia in ductules and acini of the exocrine pancreas. J. Path. Bact. 89, 569-572, 1965.

28) Ekholm, R. \& Edlund, Y. : Ultrastructure of the human exocrine pancreas. J. Ultrastruct. Res. 2, 453-481, 1958-1959.

29) Krompecher, E. : Über die Beziehungen zwischen Epithel und Bindegewebe bei den Mischgeschwülsten der Haut und der Speichel drüsen und über das Entstehen der Karzino- sarkome. Beitr. z. path. Anat. u. z. all. Path. 44, 88-149, 1908.

30) Chan Po Hon et al. : The pathology of Clonorchis sinensis (Distomum spathulatum) infestation of the pancreas. J. Path. Bact. 93, 185-189, 1967.

31) Laidlaw, G. F. : Nesidioblastoma, the islet tumor of the pancreas. Amer. J. Path. 14, 125-134, 1938.

32) Priesel, A.: Beiträge zur Pathologie der Bauchspeicheldrüse mit besonderer Berucksichtigung adenomatöser Geschwulstbildungen sowie der Anatomie. Frankfurt Ztschr. f. Path. 26, 453-518, 1922.

33) Balo, J. \& Ballon, H. C. : Metaplasia of basal cells in ducts of pancreas : its consequences. Arch. Path. 7, 27-43, 1929.

34) Yotsuyanagi, S. : Studien über das menschliche Pankreas: Mehrschichtigkeit des Ausführungsgangepithels. Tr. Jap. Path. Soc. 21, 401-411, 1931.

35) Korpássy, B. : Die Basalzellenmetaplasie der Ausführungsgänge des Pankreas. Virchows Arch. Path. Anat., 303, 359-373, 1939.

36) Wainright, C. W. : Intrapancreatic obstruction. New Eng. J. Med. 244, 161-170, 1951.

37) Andrew, W. : Tissue change in old age; similarities and differences in man and laboratory animals. Geriatrics 12, 433-438, 1957.

38) Becker, V.: Sekretionsstudien am Pankreas. Georg Thieme Verlag. Stuttgart, 1957.

39) Martin, E. D. : Analysis of the individual lesions in 180 cases of pancreatic disease. Bibl Gastroent. 7, 158-178, 1965.

40) Feldman, M. : The pancreas in the aged-an autopsy study. Geriatrics 10, 373-374, 1955.

41) Hicken, N. F. et al. : Is the reflux of bile into the pancreatic ducts a normal or abnormal physiologic process ? Amer. J. Surg 83, 781-786, 1952.

42）鍬塚登喜郎他：胆道末端の解剖とX線像並にその 臨床的意義. 日外会誌, 61, 799 801， 1960. 
43) Lowry, C. C. et al. : Squamous cell carcinoma of the pancreas. Southern Med. J. 42, 753757, 1949.

44) Berens, J. et al. : Ductal change in chronic pancreatitis. Arch. Surg. 68, 723-733, 1954.

45) Baggenstoss, A. H. : The pancreas in uremia; A histopathologic study. Amer. J. Path. 24, 1003-1017, 1948.

46) Warren, S. \& Sommers, S. C. : Pathogenesis of ulcerative colitis. Amer. J. Path. 25, 657679, 1949.

47) Stinson, J. C. \& Baggenstoss, A. H. : Pancreatic lesions associated with cirrhosis of the liver. Amer. J. Clin. Path. 22, 117-126, 1952.

48）村地悌二他：老年者の膵外分泌部線維増殖と脺臓 周囲疾患之の関連について. 浴風園調查研究紀 要, 36輯, 137 138, 昭和37年.

\section{$<$ 写真説明 $>$}

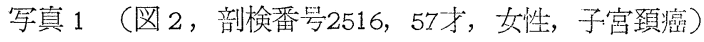

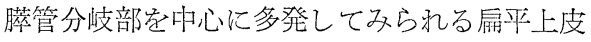
化生(黒点)，エラスティカ・ワンギーソン染色 100倍。

写真 2 (図 3, 剖検番号2741，66才，女性，糖尿病） 丽平上皮化生が膆管分岐部にあり，内腔を著し く狭窄し遠側膵管の囊状拡張と脺液のうっ滞が 認められる。PAS 染色, 100倍。

写真 3 (図 3, 剖検番号 2741,66 才, 女性, 糖尿病) 扁平上皮化生が内腔にポリープ状に突出してい る。PAS 染色, 100倍。

写真 4 （図 3，剖検番号 $2741 ， 66$ 才，女性，糖疗病） 嵋平上皮化生が管壁から間質側に向って膨隆し ている。PAS 染色，100倍

写真 5 （図 4, 剖検番号2848, 68才, 男性, 直腸癌) 唡平上皮化生による膵管の狭窄により遠位脺管 の拡張及び膵液のうっ滞，さらに限局性の腺房 拡張分認めら狆る。H. E 染色，100倍。

写真 6 (図 4, 剖㭘番号 2848,68 才，男性，直腸癌） 写真 5 の一部搪大 : 腺房の拡張及び間質の䁌加 等が認められる。H. E染色，250倍。

写真 7 （図 4 , 剖検番昂 2848,68 才，男性，直腸癌）
膵管の拡張, 膵液のうっ滞及び限局性の変化, 即ら間質の増加及び腺房細胞の唡平化など認め られるPAS 染色，100倍。

写真 8 (図 5, 剖検番号 2434,51 才, 女性, 急性骨髓 性白血病）

殿平上皮化生が管壁を全周にわたって環状に置 きかえている。H. E 染色，100倍。

写真 9 (図 5, 悋検番号2434, 51才) 女性, 急性骨髄 性白血病）

扁平上皮化生が内腔にポリープ状に突出してい る。又，分岐部付近に別に扁平上皮化生が認め られる。H. E染色, 100倍。

写真10（図 5，剖検番号2434，51才，女性，急性骨髄 性白血病）

限局性の变化，即ち，小葉間線維化が認められ る。エラスティカ・ワーギソン染色，40倍。

写真11(図 5, 剖検番号2434, 51才, 女性, 急性骨髄 性白血病）

写真100拡大：小葉間線維化及び腺房の疎開が 認められる。H. E染色，100倍。

写真12（剖検番号3528，73才，男性，肺癌） 杯細胞化生，一部では腺房まで及えでいる。 H.E染色, 100倍。 
写真 1
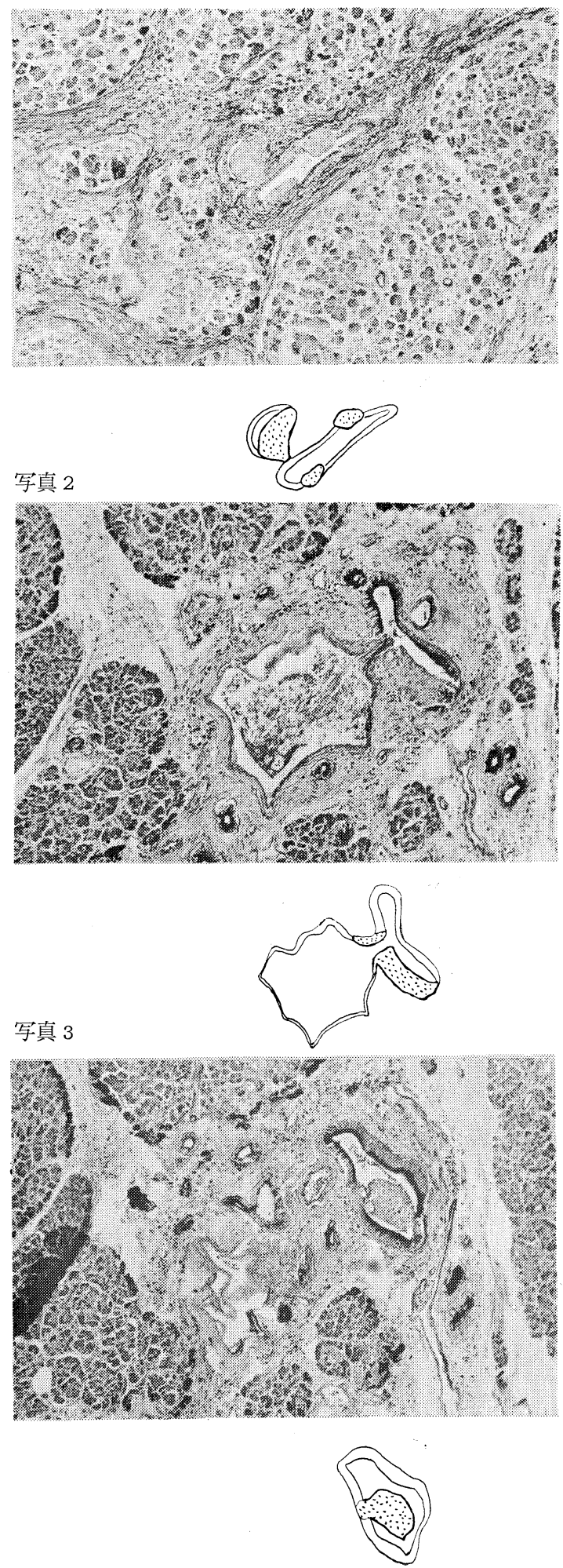

写真 4
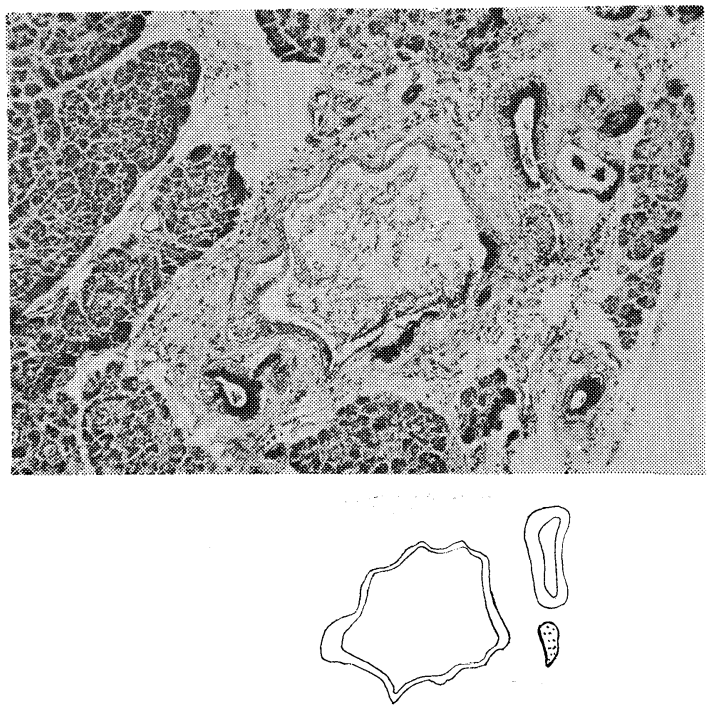

写真 5
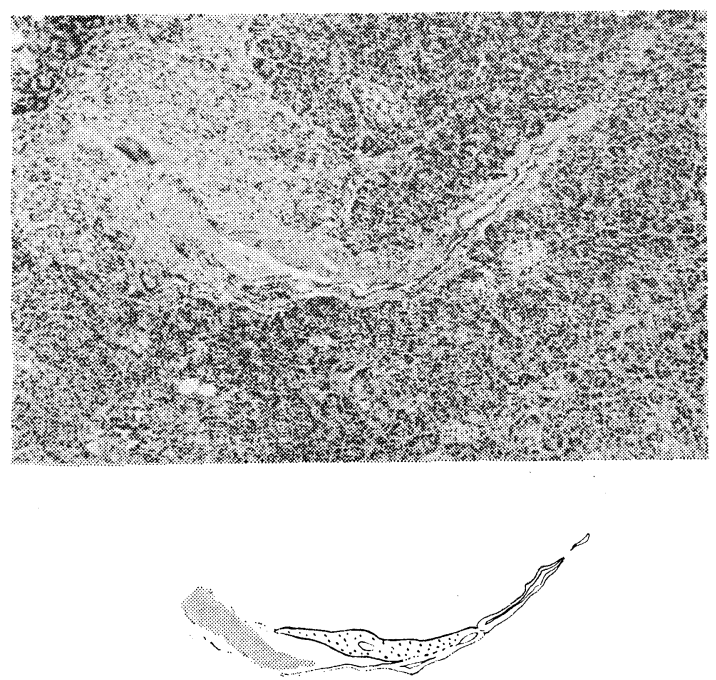

写真 6

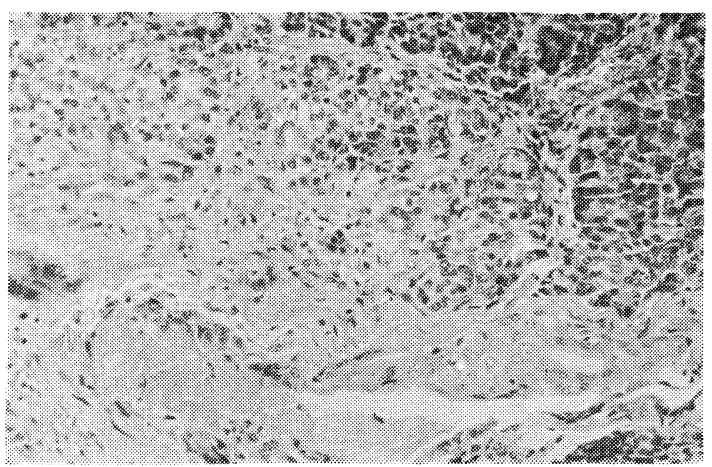




\section{写真 7}

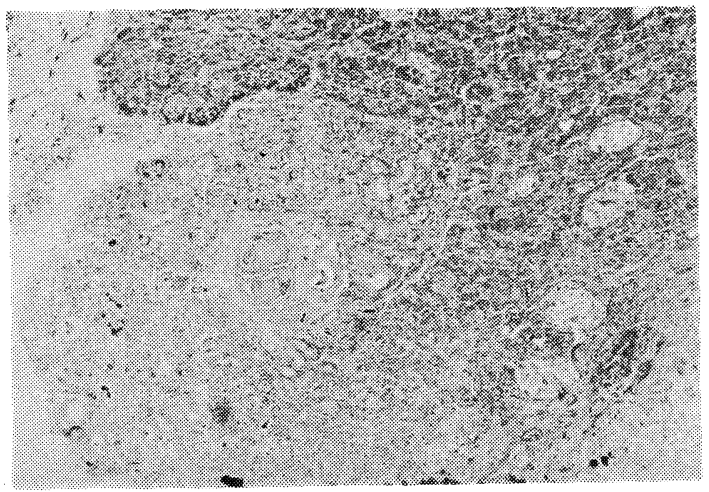

写真 8
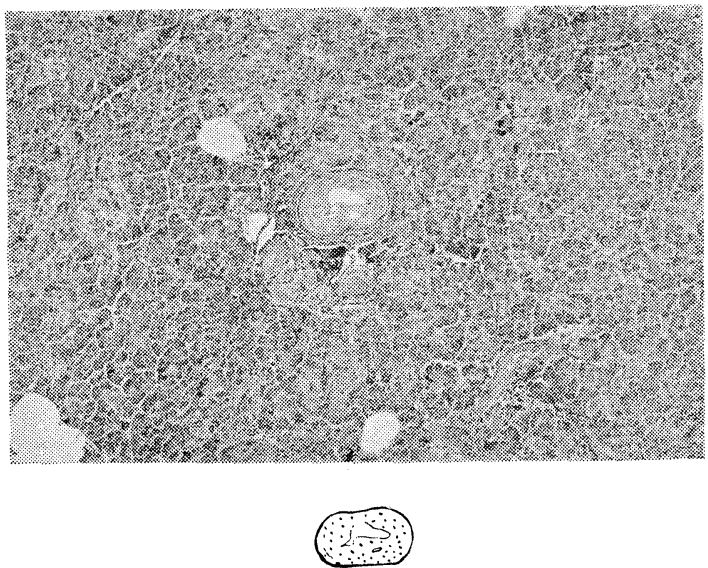

写真 9
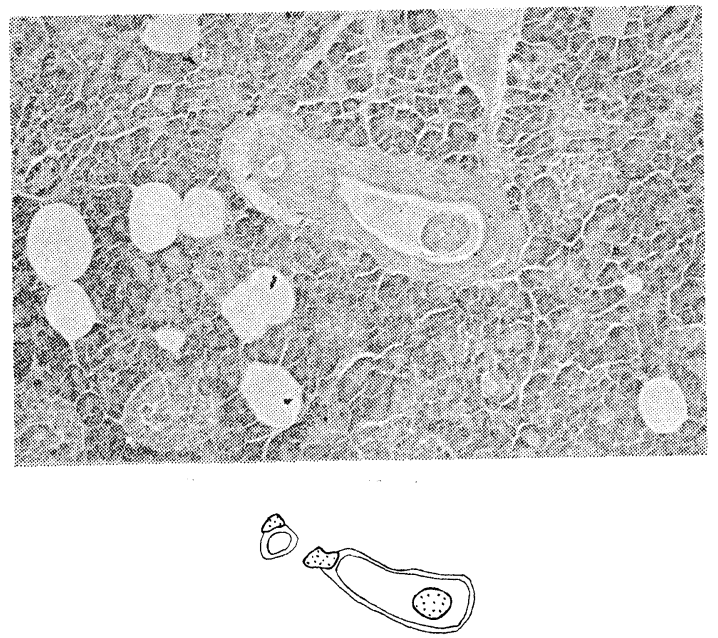

写真 10

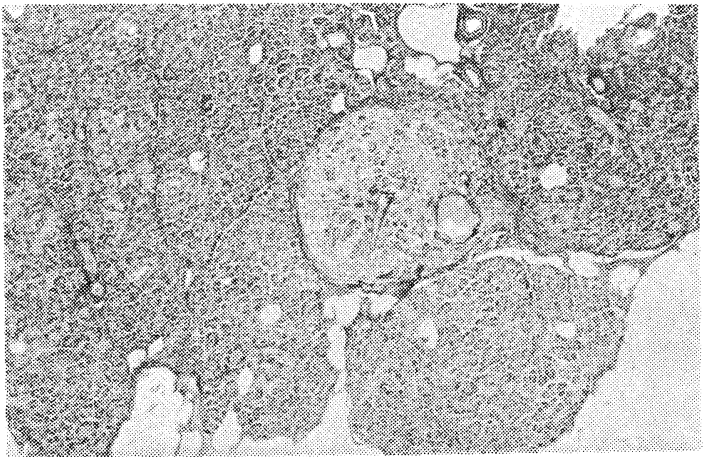

写真 11

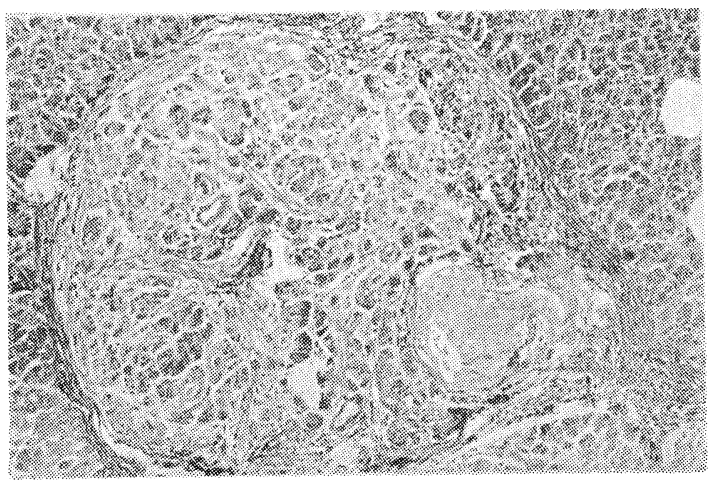

写真 12

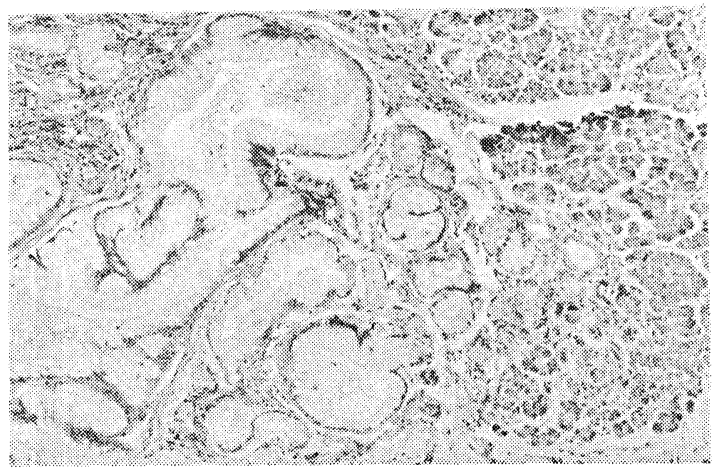

